\title{
Changes in Ecological Landscape Pattern and Land Use from 1985 to 2014 in the Panshet Dam Catchment
}

\author{
Manasi Karandikar, Vrishali Dumale, Shailaja Deshpande
}

Manasi Karandikar is co-founder and managing partner at oikos for ecological services since 2002. She is also Faculty, Trustee and core team member at Ecological Society, Pune. She was member of HLMC, Matheran during 2012-2014. She has written articles in magazine and news papers, co-authored a book on Nature conservation, and published databases on Native plants.

Email : manasi@oikos.in

Vrishali Dumale is co-founder and director of Geospatial Solutions, Pune.

Shailaja Deshpande, is an active volunteer and alumni of Ecological Society. She has worked as a Project Coordinator at Ecological Society on a project funded by Global Forest Watch in the Panshet Catchment area. She is currently working on revival of Rivers of Pune, under Jeevitnadi Initiative.

\begin{abstract}
The Sahyadri, the northern part of Western Ghats in the state of Maharashtra, India, are one of the most fragile ecosystems on Earth. There are major changes in the original ecosystem and land use in the Sahyadri over the past two centuries.

A ground survey was conducted by Ecological Society, Pune in 1985 as well as in 2014 to assess current land use and status of biodiversity in the Panshet dam catchment situated in Sahyadri. This study probes to understand factors responsible for decline of biodiversity and changed land use. We highlight the extent and causes for change in land use.

The study attempted to quantify this change by carrying out manual digitization of multispectral WV-2 satellite images by visual interpretation and ground truthing and compare with the study done by Ecological Society in 1985.

The mapping of the catchment area shows that areas towards western escarpment i.e. away from the dam wall have retained better vegetation cover while degradation is evident in eastern parts of the catchment.

Such studies will be useful for land use planning, understanding cost-benefits of nature conservation, assessing restoration potential, and developing conservation-restoration strategies on a regional scale. We recommend similar vegetation and land use class mapping for all dam catchments in the Western Ghats.

Keywords : Sahyadri, Northern Western Ghats, Panshet, Pune, Land use pattern, Landscape, forest, GIS mapping, visual interpretation, vegetation class mapping, landscape-based ecosystems management, dam catchments
\end{abstract}

\section{Acknowledgements}

The 2014 study of the Panshet catchment was conducted by Ecological Society under the Small Grants Program of Global Forest Watch (GFW). We sincerely thank GFW for making the project possible. Special thanks to the entire team which worked on this project, for their hard work on field in these remote parts of Sahyadri. The staff of Forest Department and Irrigation Department, State of Maharashtra, was very supportive during surveys and also shared data important for the project.

\section{Introduction}

\section{The Western Ghats}

The Western Ghats (WG) stretch nearly $1600 \mathrm{~km}$ along south-west peninsular India and stand testimony to several million years of geological history. The WG are the mountain range that is separated from the Arabian Sea by a narrow strip of the coastal plains of India. The hill range of WG has been recognized as one of the world's 35 biodiversity hotspots, i.e. a region of rich biodiversity threatened with destruction. It is 
one of the world's eight hottest hotspots and declared as a World Natural Heritage site by UNESCO (Unesco, 2012).

There have been many studies about biodiversity and ecosystems of the W. Ghats, documenting changes in forest vegetation, threats, and conservation needs. Even though they do not contain specific mentions of forests and ecosystem health in Western Ghats, the Gazetteers of past governments mention the richness of flora and fauna present in immediate surroundings of town centers present at that time. From these references, it is evident that the forests of Western Ghats were more or less intact till 1836-37, when the revenue survey was introduced by the British India government. After this, forests in Western Ghats started converting slowly into cultivation plots for hill millets locally, and into monocultures of timber species as well as tea plantations in Southern parts. For several decades, the conversion for cultivating hill millets was low relative to the overall area of WG and there was a chance of it regenerating into a secondary forest during fallow period.

Land use change accelerated in the $20^{\text {th }}$ century with the development of irrigation reservoirs in these high rainfall areas - the key reasons being submergence of fertile valley bottoms, hill communities being displaced to higher slopes, cultivation of slopes for millets, and extraction of coal for urban centers due to easy access to these remote parts (Gadgil 1979). This continued through the British period and after India's independence.

A study by (Jha, Dutt, Bawa, July 2000), which uses GIS mapping over 40,000 sq $\mathrm{km}$ of area in Southern Western Ghats showed 25.6\% loss of forest cover in 22 years (1973 to 1995). It was also observed that the dense forest was reduced by $19.5 \%$ and open forest by $33.2 \%$.

In Sahyadri, the number of reservoirs is very high, with almost all the rivers dammed in the source area. A similar situation was documented by (Gadgil M, 1979) and (Gole P., 1985) in their studies in dam catchments of Panshet, Warasgao and Mulshi near Pune.

\section{Rationale for the study}

"Land is the basic component of the natural resource system of any country. Natural resources are fundamental to sustainable economic development in most countries, particularly Asian developing countries where agriculture remains an important source of economy. Natural resources are increasingly subjected to intensive population pressure, widespread poverty and expansion of industrialization and urbanization. The rapid change in the socio-economic patterns of these countries has inevitably and adversely affected the natural resources. Natural resource problems have now become a major concern of development planners as they attempt to promote rapid development. These problems are partly caused by mismanagement of resources through serious exploitation." (Onchan Tongroj, 1993)

The above quote is pertinent in case of Sahyadri, where the forest cover is fast depleting due to development pressures. The reasons include agriculture, new roads, widening of existing roads, farm houses, recreational sites, hill stations, townships, horticulture and greenhouses, small-scale industrial units, and large-scale industrial activity like SEZs or new plants.

Availability of data and observations regarding ecological landscape of Panshet catchment from 198586 triggered the present study. We planned to assess land use changes occurring in the Panshet catchment after almost 30 years as this may guide further directions in planning.

\section{Study area}

\section{Location and Physiography}

The Panshet dam catchment, which is the area for the present study, lies in Sahyadri (Northern Western Ghats). It is situated at approximately $40 \mathrm{~km}$ west of Pune city and is a major irrigation and water supply project in the region.

The dam catchment is spread over $118.6 \mathrm{sq} \mathrm{km}$, extending from $73^{\circ} 26^{\prime} 7.947^{\prime \prime} \mathrm{E}$ and $18^{\circ} 17^{\prime} 43.6411^{\prime \prime} \mathrm{N}$ to $73^{\circ} 37^{\prime} 44.686^{\prime \prime} \mathrm{E}$ and $18^{\circ} 23^{\prime} 14.33^{\prime \prime} \mathrm{N}$ with elevations ranging from $626 \mathrm{~m}$ at valley to $1134 \mathrm{~m}$ at the ridge line (Pole village). The waterbody of Panshet dam is spread over $14.5 \mathrm{sq} . \mathrm{km}$.

The River Ambi, an eastward flowing river originates at Dapsar and is bound by two main hill ranges running west to east separated by average distance of $6.6 \mathrm{~km}$ (Figure 1, 2, 4).

The catchment of Ambi comprises of twenty five mini watersheds (Figure 3).

\section{Rainfall}

The rainfall data shows variation from average annual $9000 \mathrm{~mm}$ at Western escarpment at village Dapsare, to $2100 \mathrm{~mm}$ at village Panshet where the dam is built. The 1985 study by Ecological Society divided the catchment into 4 zones (Figure 5).

Distribution of rainfall becomes an important factor as it decides natural vegetation character in the valley. 

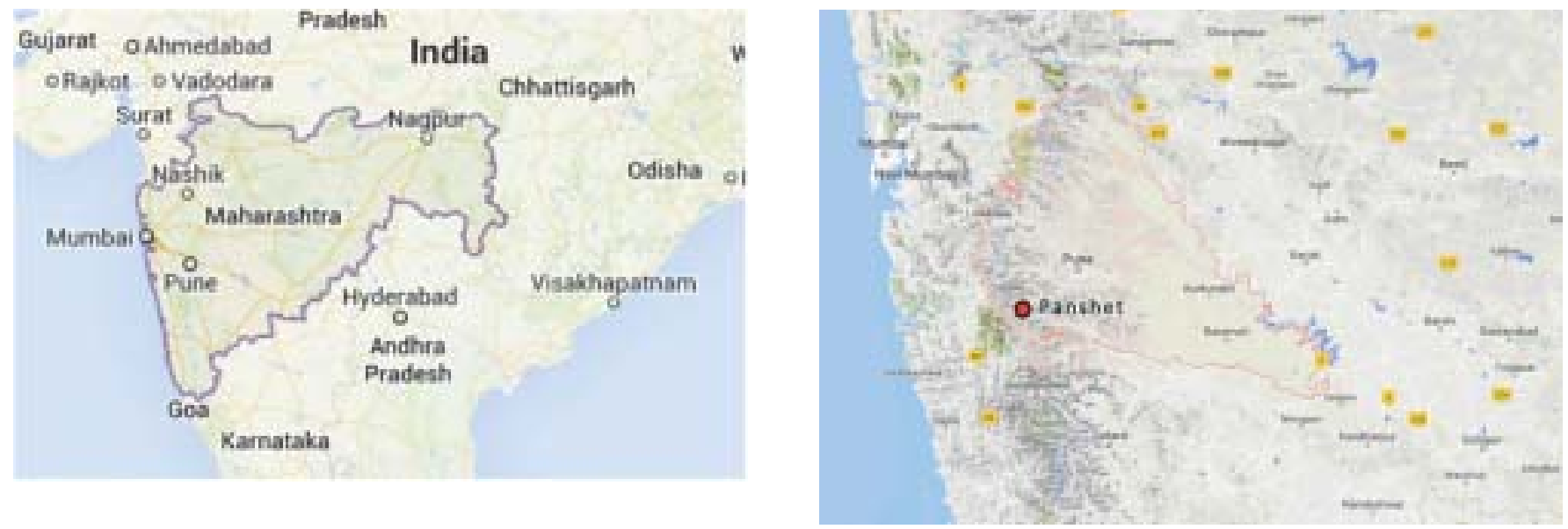

Figure 1, 2 : Location: Panshet dam catchment

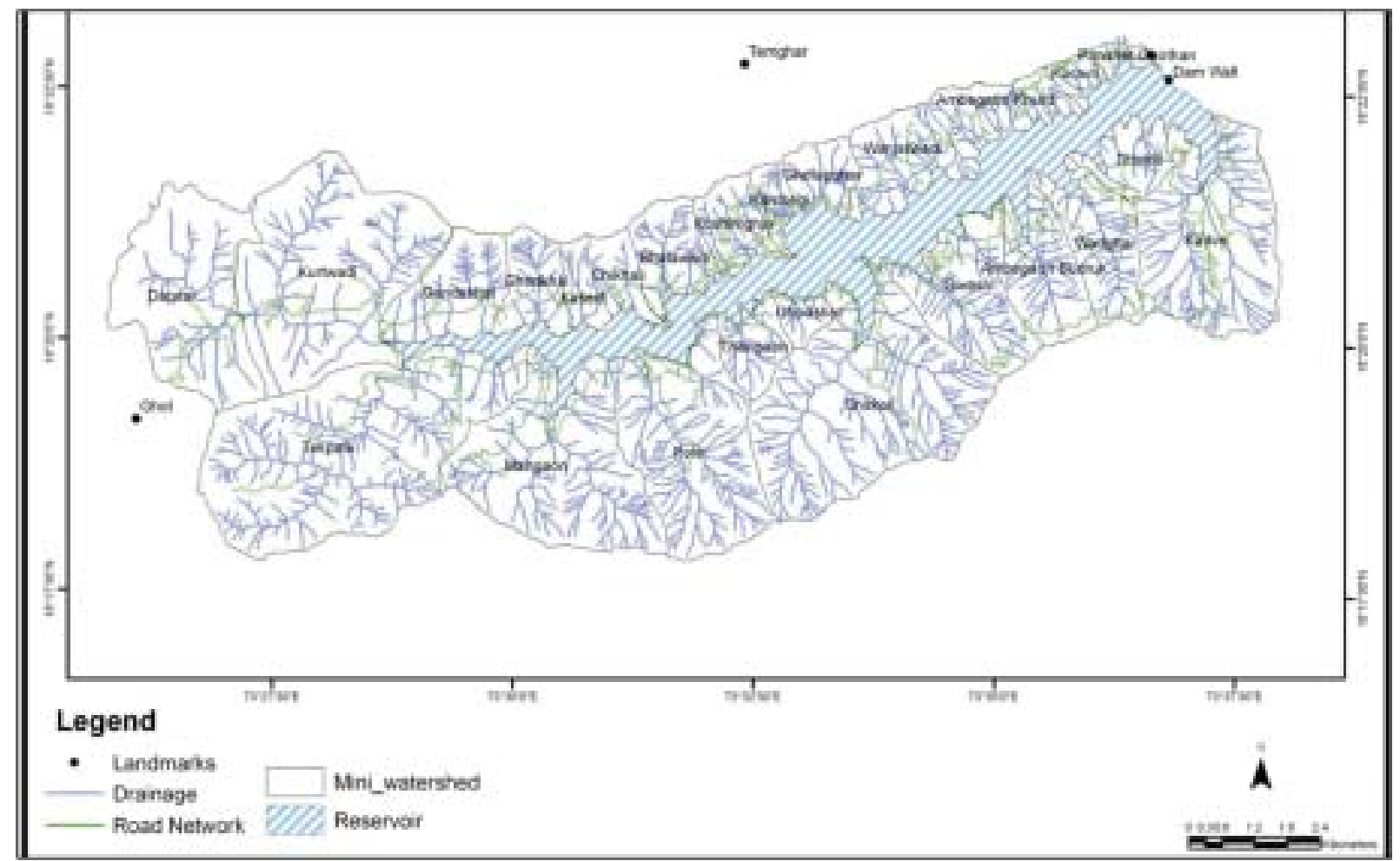

Figure 3: Hydrology of Panshet dam catchment 


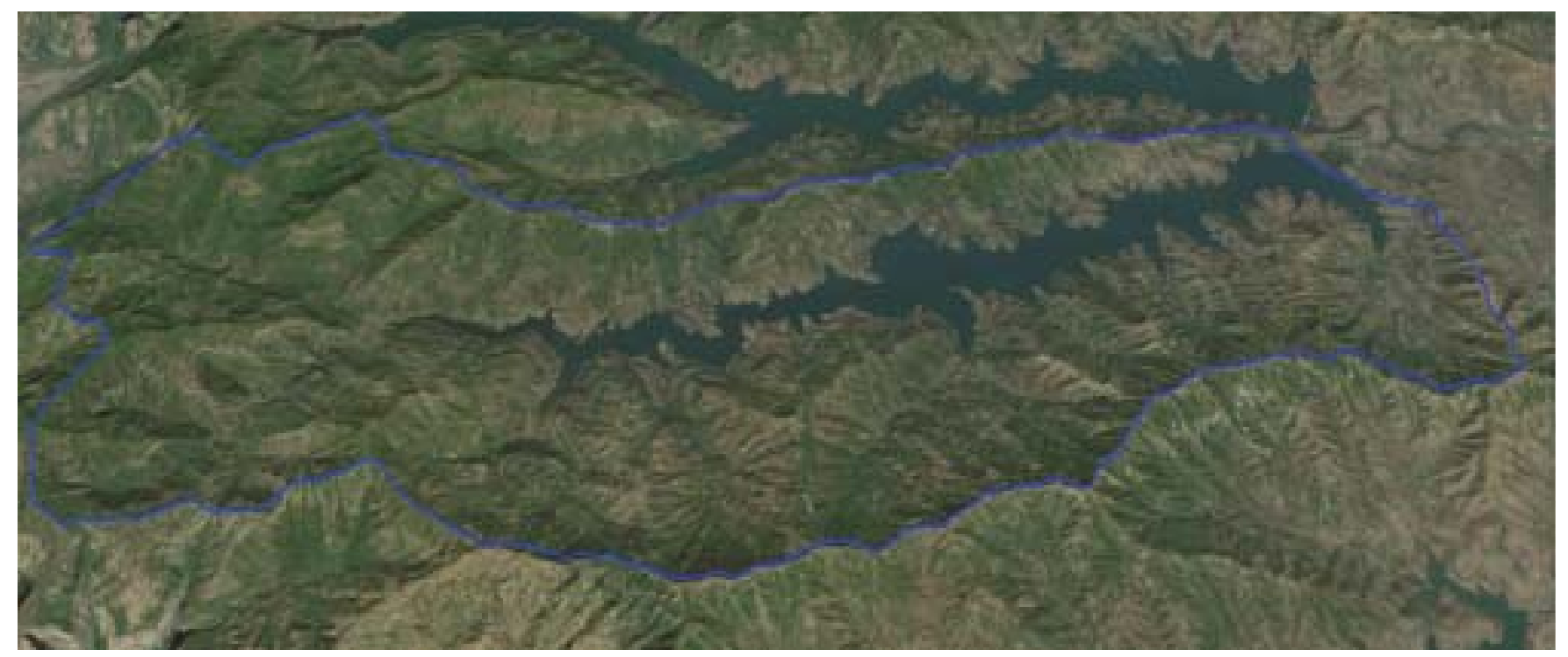

Figure 4: Physical map : Panshet catchment

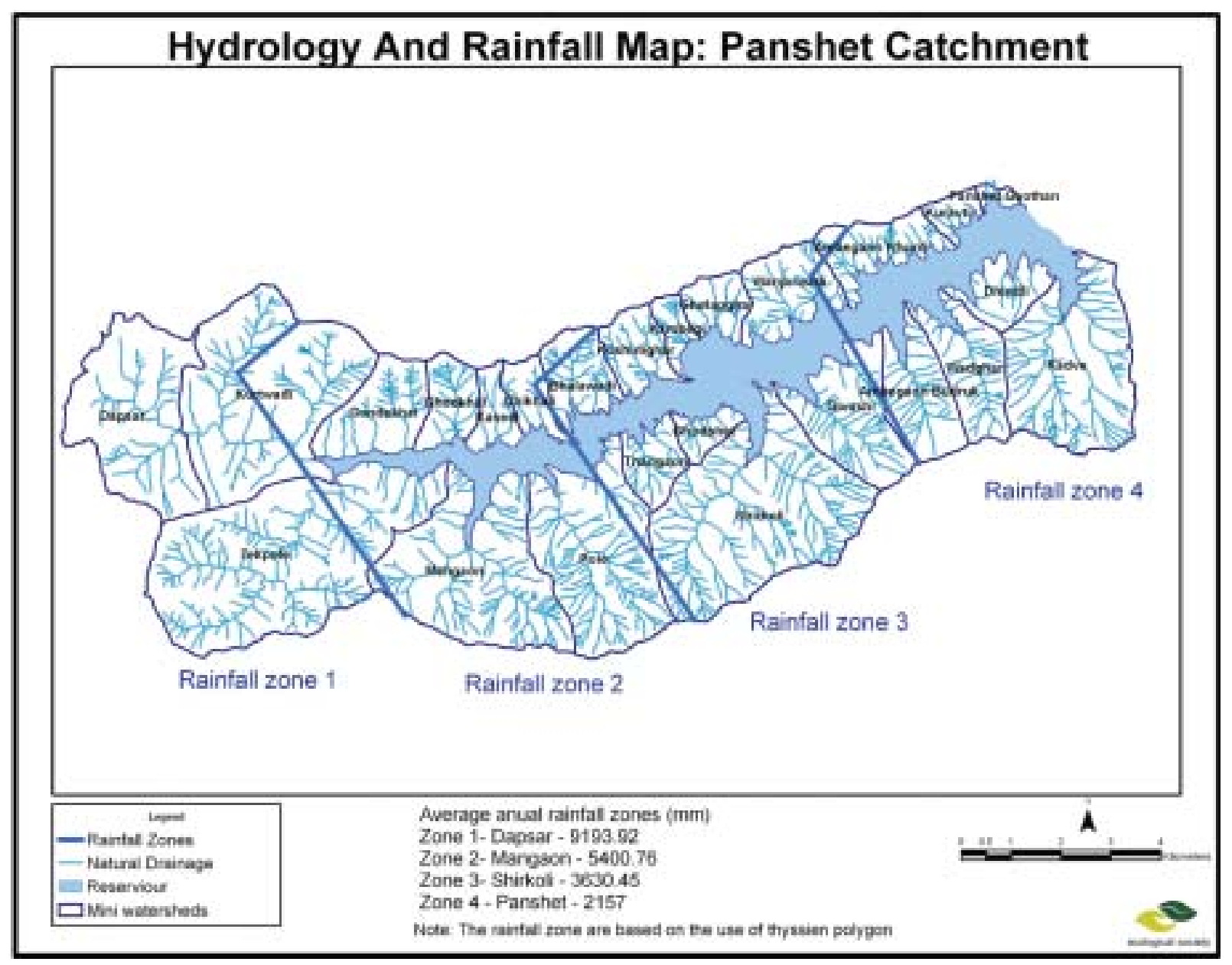

Figure 5: Panshet catchment : Rainfall zones 
The variability in precipitation and topographical features create a wide range of vegetation types from semi-evergreen forests to moist deciduous, scrub to open grasslands and rocky outcrops.

\section{Earlier Studies about the Study Area}

Earlier studies of the Panshet catchment have studied the ecosystem, biodiversity, socio-cultural practices like Sacred Groves and land use. (Gadgil, M. and Vartak, V.D., 1976) mention that hill slopes fairly remote from the villages were still covered by some forest. Until about twenty years before the time of this study, the whole region was much better forested, particularly because the peasants left valuable trees standing even when they cleared a plot for cultivation.

The upper hill slopes were clothed by a rich natural forest of the semi-evergreen type, constituted into stateowned forest reserves. These forests were hardly exploited due to lack of transport facility. Prof. Gadgil also mentions a flourishing tanning industry at Bhor, near Panshet which was entirely based on Hirda (Terminalia chebula) collection from forests in these catchments which gradually declined as majority of forests were cut for coal by 1960. (Gadgil M, 1979)

Prof. Gole, with his detailed study of Panshet catchment in 1983-84 with respect to the ecosystem and socio-economic aspects, concludes that construction of the dam and allied activities led to speedy destruction of the original forest ecosystem in the catchment. The major reasons leading to this destruction are: submergence of fertile land, social dynamics of communities and resettlement, and construction of a ring road giving access to the urban market for coal. (Gole P., 1985)

\section{Objectives of the 2014 study}

The objectives of the present study (2014) are given below :

1. To prepare land use, land cover (LULC) maps for the Panshet catchment and to derive area estimates of vegetation and human land use classes

2. To survey and document biodiversity in various land classes

3. To evaluate degree of degradation by comparing the present data with data from 1985 study. We planned to use the 1983-85 primary data set as a reliable record of past biodiversity status

4. To prepare a restoration potential map

Land use and land cover is an important component in understanding the interactions of the human activities with the environment. Keeping these factors in mind GIS techniques and traditional surveying methods were used to get a real picture of the present land use and biodiversity status of the catchment.

\section{Methodology}

\section{GIS analysis}

High spatial resolution multi-spectral satellite image was used for visual interpretation. Standard WorldView-2 (4 band) images for 2013-14 were used. Land Use-Land Class (LULC) mapping for 2014 was obtained by manually digitizing the image. Data from the 1983-85 study was used to create a digital version of Land Use-Land Class mapping of that time.The datasets were then incorporated in ArcGIS 9.2 to convert that data into meaningful information.

Note: In case of smaller objects like ponds, water tanks, small shifting cultivation patches etc, the scale was temporarily changed.

\section{Methodology Steps}

The following methodology was adopted :

1. Generation of maps for all the input layers.

2. Hydrology: The natural drainage pattern was digitized taking toposheets as base. The contour pattern was studied and accordingly the drainage, mini-watersheds and entire watershed boundary was delineated. The drainage pattern was updated with the help of the false color composite (FCC).

3. Rainfall: Based on secondary data from the Meteorological Department, the project area was divided in four zones considering the average annual rainfall. The zones were derived based on the Thiessen polygon method.

a. Zone 1- Dapsar- $9193.92 \mathrm{~mm}$

b. Zone 2- Mangaon- $5400.76 \mathrm{~mm}$

c. Zone 3- Shirkoli- $3630.45 \mathrm{~mm}$

d. Zone 4- Panshet- $2157 \mathrm{~mm}$

4. Mapping of Stream Habitat: The streams were digitized from the satellite image. The habitat of riparian zone along the rivers was mapped.

5. Ground Survey for biodiversity and land use classes : A Stratified Random Sampling approach was followed for ground survey. Based on the past experience of the team in this landscape, analysis of Google Earth images, observations from reconnaissance visits, and variation in land classes, we selected 47 randomly distributed areas and completed their detailed on-ground biodiversity survey over a period of 6 months. 
These randomly sampled 47 points represent all the vegetation classes as well as physical conditions in the valley. These 47 points also covered all rainfall zones. As the focus of the study was to map special biodiversity of the catchment, this methodology served us well. However, the overall observations were not restricted only to the selected 47 points. Biodiversity was observed all along the catchment.

The images available were of two different seasons; one for $18^{\text {th }}$ May 2013 and another for $28^{\text {th }}$ Jan 2014. They were both World view 2- 4 band multispectral pan-sharpened satellite images. Both the images were used simultaneously to eliminate any wrong classification. The scale was set to 1:3000 for almost the entire watershed area. The final layer was then rechecked for any mismapping.

During the ground survey of sample points, the latitude, longitude and elevation was collected with the help of a hand held GPS device. Associated biodiversity was documented in standard formats.
This format includes Endemism, IUCN status, and legal status of each species. The other information is location, brief description, area, co-ordinates, altitude, dominant flora, old growth flora, tall canopy flora, species with IUCN status, Indian forest department's scheduled species and photos. Vegetation classes were identified based upon current floral composition. Vegetation composition also changes due to anthropogenic activities including agriculture.

As the land classes have been drawn by manual digitization, the maps are the true representation of the real topography. Due to this method, the possibility of inaccuracy creeping in due to automated classification has been ruled out.

\section{Vegetation and Land Use Classes}

Following are the natural and human-influenced vegetation classes which were mapped in the form of polygons. The determination of land classes is based on their key vegetation characteristics and is similar to that proposed in Ghate (2014).

\begin{tabular}{|c|c|}
\hline No. & Class \\
\hline 1 & Open grasslands \\
\hline 2 & Scrub \\
\hline 3 & Sparse vegetation \\
\hline 4 & $\begin{array}{l}\text { Karvi (Carvia callosa) } \\
\text { patches }\end{array}$ \\
\hline 5 & $\begin{array}{l}\text { Karvi (Carvia callosa) } \\
\text { and dwarf canopy }\end{array}$ \\
\hline 6 & Dense shrubbery \\
\hline 7 & $\begin{array}{l}\text { Sparse vegetation } \\
\text { dominated by trees }\end{array}$ \\
\hline o & Dwarf canopy forests \\
\hline 9 & Mature forests \\
\hline 10 & Tall canopy \\
\hline 11 & Potential stream habitat \\
\hline 12 & Rocky outcrop \\
\hline
\end{tabular}

Description

Areas with grasses as the dominant community

Areas which combine evergreen thorny scrub vegetation with interspersed grass patches

Areas with not too many grass patches but large clusters or regenerating trees Areas with uniform Karvi (Carvia callosa) patches

Areas with Karvi (Carvia callosa) patches and low height canopy trees

Areas with dense shrubs of similar height

Areas with shrub cover dominated by regenerating trees

Areas with mixture of shrubs, regenerating dwarf trees

Areas with original forest vegetation

Areas with fairly dense cover with tall canopy trees

Areas of stream-sides with dense tree vegetation

Areas with occurrence of rocks and boulders, and less soil cover

Areas with vertical rock faces (usually inaccessible) and retaining original vegetation of rocky outcrop

Table 1 : Vegetation classes 
Apart from the above classes, there are man-made land use classes spread over the entire catchment.
These are due to cultivation practices and modern developmental trends. These classes are :
No. Class

1 Agriculture

2 Plantations

a. Non-native Plantations

b. Bamboo Plantation around Settlement

c. Horticulture

d. Old Non-native Plantations with regenerating natives

3 Road and Areas Affected By Road

4 Bamboo Plantation

5 Modern Development

6 Quarry

$7 \quad$ Shifting Cultivation

Patches

8 Settlements
Description

Permanent areas under cultivation, i.e. Paddy fields and other crops

Plantations by local people, various government departments, or private land owners.

Tar road and areas affected by road construction activity

Independent Bamboo plantation, typically for income generation Farm house schemes, recreational sites, existing residential infrastructure, semi-urban areas, etc.

Earth or stone extracted for construction

A practice in this area which uses slopes for cultivation. These are patches of land used for cultivating hill millets for 2 or 3 years.

Villages and areas around them

Table 2: Human-influenced land use classes 
A chart describing the data collection and analysis process is given below :

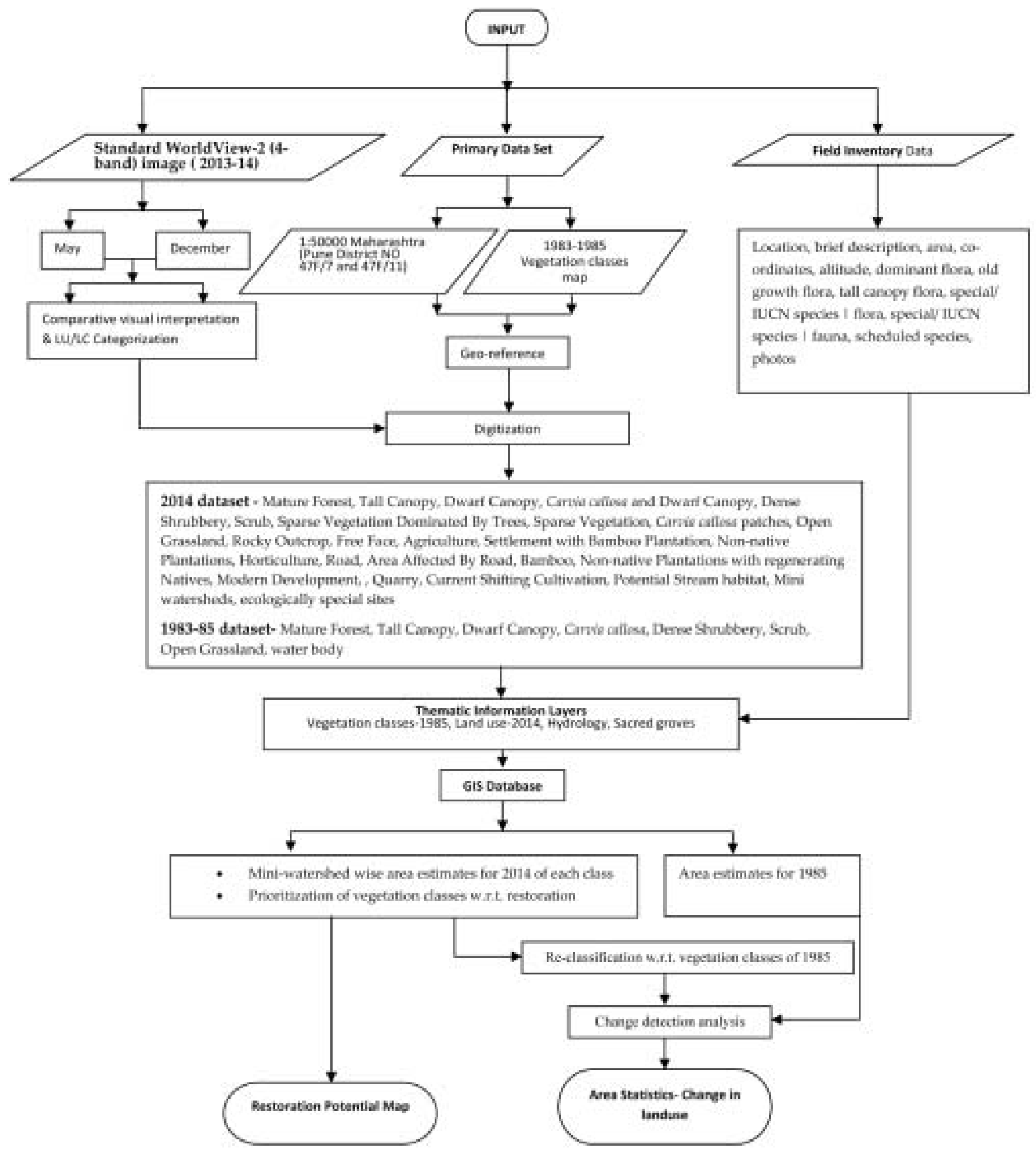




\section{Analysis}

\section{Primary Data set}

Data was available in the form of tables, maps and text for the year 1983-85 (Gole P., 1985). In this earlier work, a hand drawn "vegetation classes" map was geo-referenced and then manually digitized. However, the vegetation classes were presented based on the species dominance. Hence, they were reclassified into new vegetation classes per our present classification and the 1983-85 map was re-produced by utilizing the association in table below. The association itself is based on the field observations of the authors and Ecological Society over the last several years in W.
Ghats. Area estimates were carried out based on this map for the year 1983-85. This map is presented in Figure 8.

\section{Land-use land-cover analysis for the year 2014}

The satellite images used are shown in Fig. 6 and 7 (Note : Vegetation appears in red color).

\section{Results and discussion}

\section{Land-use land-cover map for 1985 study}

As discussed above, the historical data available was used to prepare 'vegetation classes' map of 1985 and an area statement was derived from it.

\section{No Species-dominant class as per [Gole P, 1985]}

1 Actinodaphne hookeri Heissm, Glochidion hohenackeri Bedd

2 Bridelia squamosa Gehrm, Terminalia tomentosa W

3 Butea monosperma Taub, Xeromphis spinosa Keay

4 Dendrocalamus strictus Mees, Syzygium cumini Skeels, Strobilanthes Sp

5 Erythrina variegata Merr, Euphorbia neriifolia Roth

6 Heteropogon contortus P. Beauv, Themeda quadrivalvis O. Ktze

7 Latana camara L

8 Latana camara L- Carissa congesta Wight

9 Mangifera indica, Memecylon umbellatum Burm, Syzygium cumini Skeels, Ficus spp

10 Memecylon umbellatum Burm, Ficus sp

11 Phoenix humilis Bess, Dendrocalamus strictus Mees

12 Reserved Forest

13 Reservoir

14 Sacred Grove, Mangaon

15 Strobilanthes callosus Mees

16 Syzygium cumini Sxeels, Wendlandia ihyroidea, Macaranga peltata Muella

17 Terminalia tomentosa $\mathrm{W}$ and $\mathrm{A}$

18 Terminalia tomentosa W and A, Emblica officinalis Gaeri

19 Woodfordia fruticosa Kurz, Lasiosiphon eriocephalus Ocme

\section{Reclassified class \\ Dwarf Canopy \\ Dwarf Canopy \\ Dwarf Canopy \\ Dwarf Canopy \\ Scrub \\ Open grassland \\ Open grassland \\ Open grassland \\ Tall canopy \\ Tall canopy \\ Dwarf Canopy \\ Tall canopy \\ Water body \\ Mature forest \\ Carvia callosa \\ Dwarf Canopy \\ Open grassland \\ Open grassland \\ Scrub}

Table 3 : Table showing reclassification of species-dominant classes from the 1985 study

Note : As the 1985 map is a hand drawn map, there could be statistical inaccuracies in the area computation of the land classes. Yet, this is the best source available for a comparative study. 


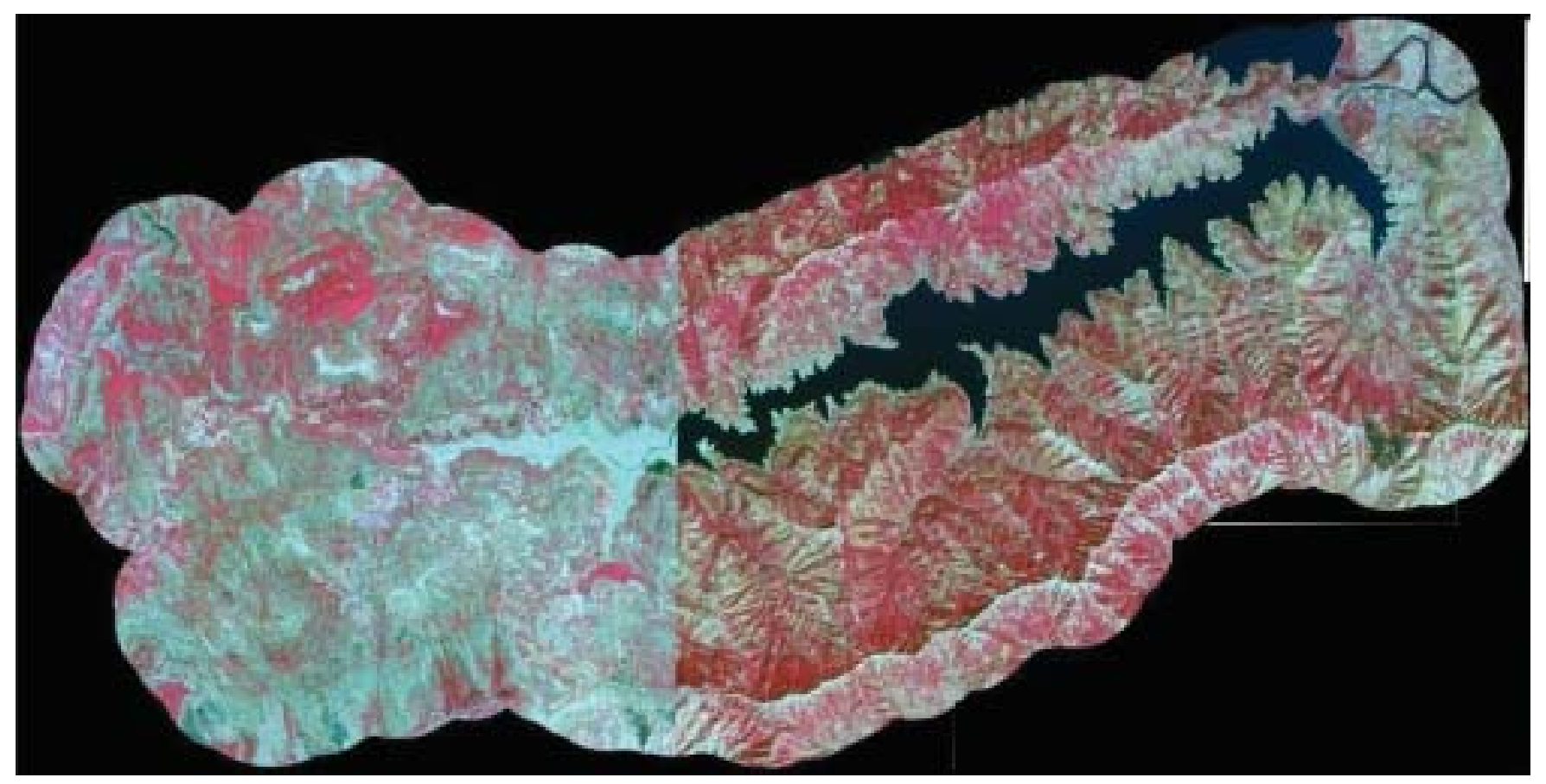

Figure 6: Worldview -2 Pan-sharpened multispectral image - May 2013

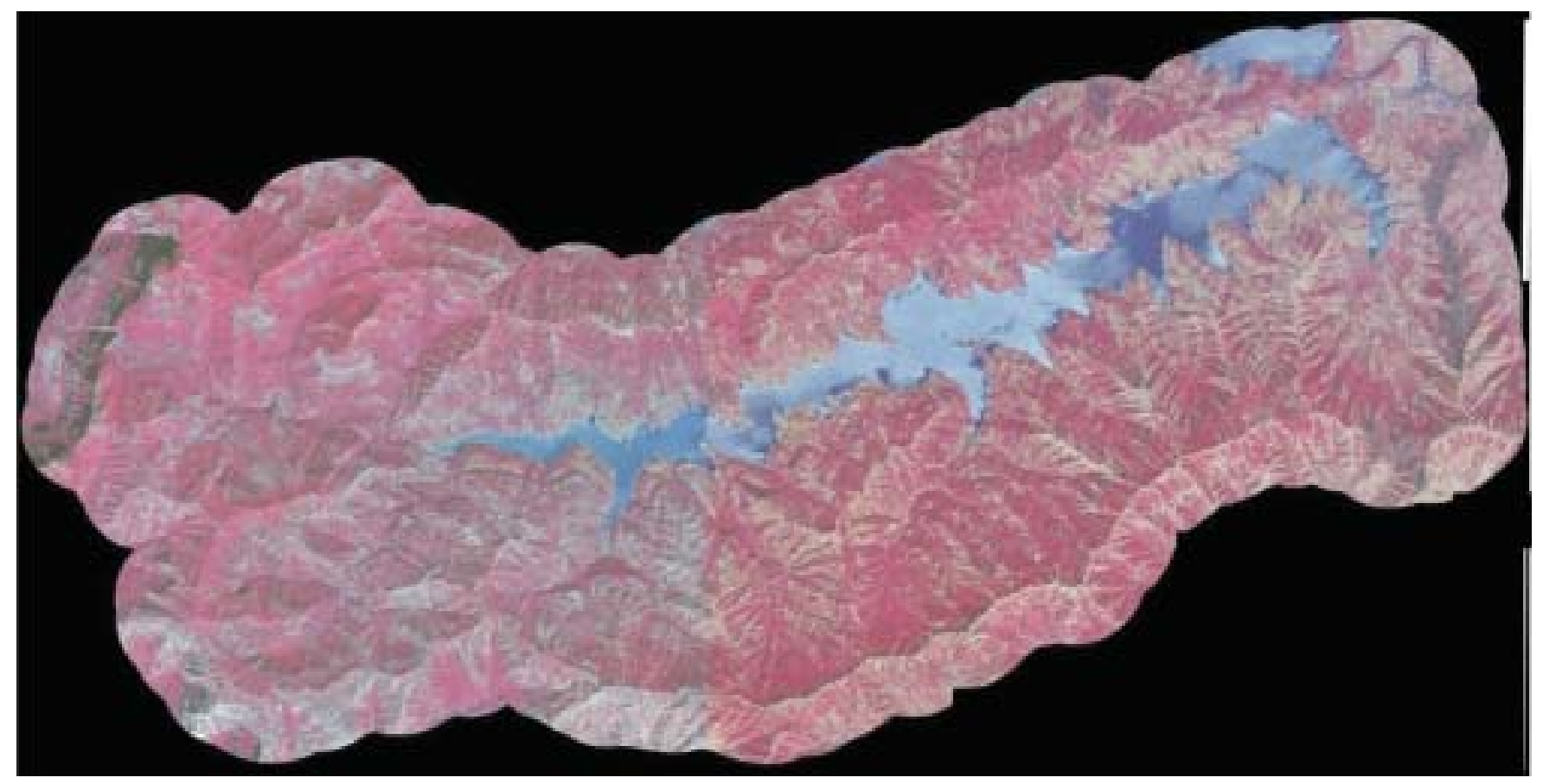

Figure 7 : Worldview -2 Pan-sharpened multispectral image - Jan 2014 


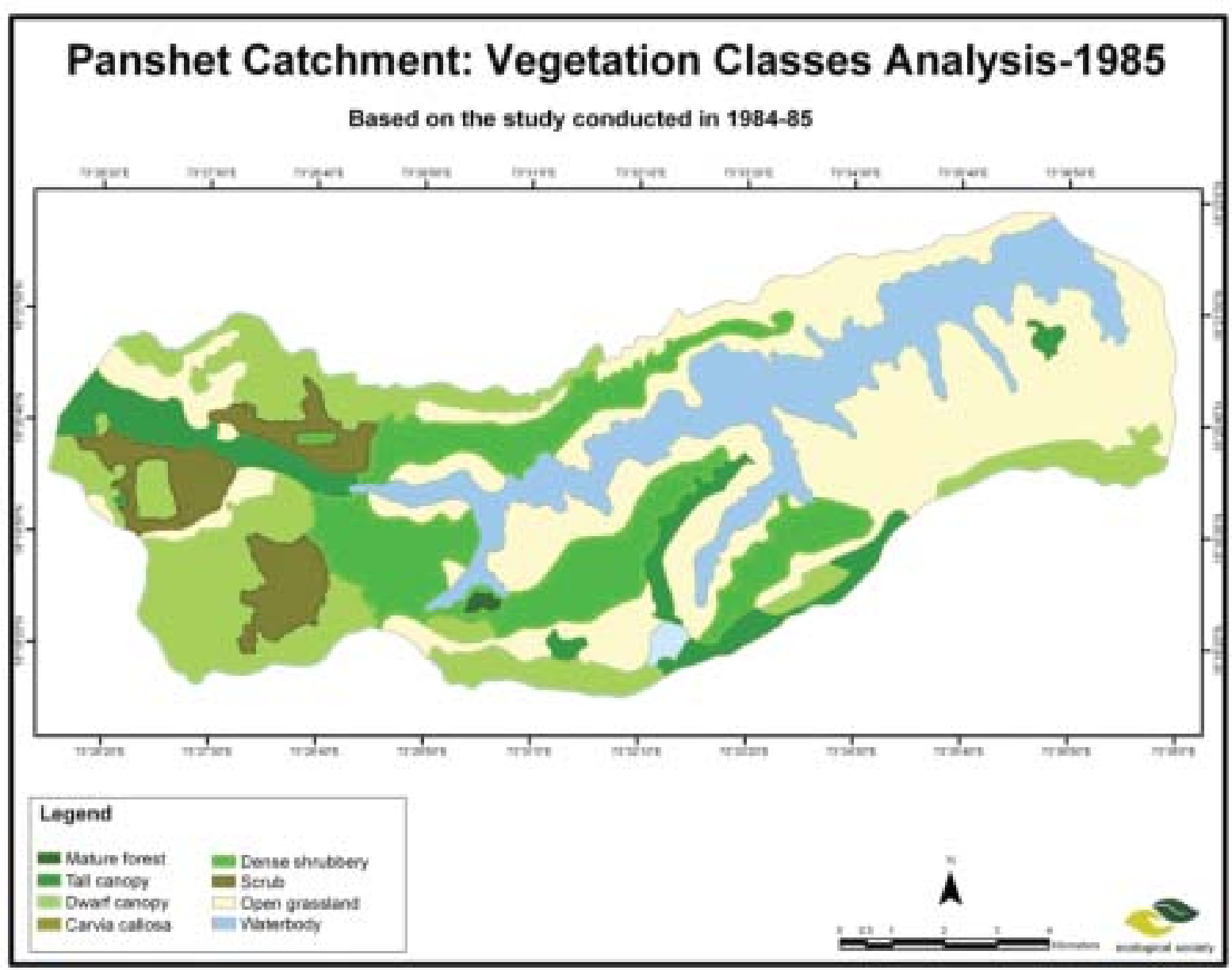

Figure 8: Vegetation classes map - 1985

The area estimate for the above land use land cover map is given in the table below :

Area Statement for Panshet Catchment based on [Gole P,1985]

$\begin{array}{llrr}\text { Sr. No } & \text { Class } & \text { Area (Acres) } & \text { Percentage of the total catchment } \\ 1 & & & \\ 2 & \text { Dense shrubbery } & 4550.18 & 15.73 \\ 3 & \text { Dwarf canopy } & 5413.48 & 18.72 \\ 4 & \text { Carvia callosa } & 113.09 & 0.39 \\ 5 & \text { Mature forest } & 50.87 & 0.17 \\ 6 & \text { Open grassland } & 10507.10 & 36.34 \\ 7 & \text { Reservoir } & 4566.17 & 15.79 \\ 8 & \text { Scrub } & 1908.67 & 6.60 \\ 9 & \text { Tall canopy } & 1802.83 & 6.23 \\ & \text { Human Use } & \text { Not assessed separately } & \text { NA } \\ & \text { Total } & \mathbf{2 8 9 1 2 . 4 3} & \mathbf{1 0 0 \%}\end{array}$

Table 4: Land-use land-cover area estimate for the 1985 study 
Land-use land-cover map for 2014 study

Based on the land use pattern, the area under study was classified into 24 different classes. The classification was based on the methodology described earlier.

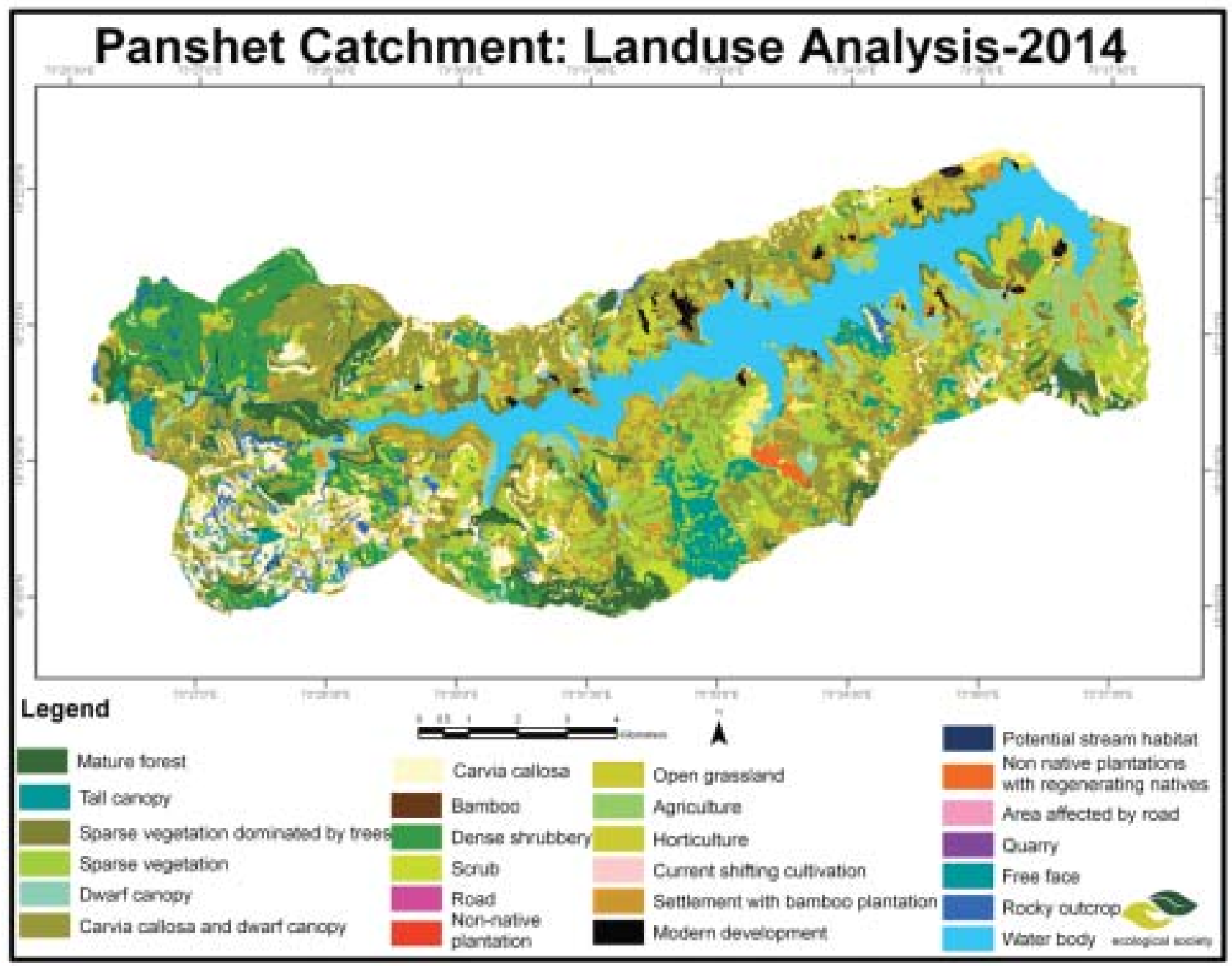

Figure 9: Land-use land-cover map - 2014 
The area estimate for the above land use land cover layer is given in the table below :

Sr. No. Vegetation Class

2

3

4

5

6

7

8

9

10

11

12

13

14

15

16

17

18

19

20

21

22

23

24

25

\author{
Mature Forest \\ Tall Canopy \\ Dwarf Canopy \\ Carvia callosa and Dwarf Canopy \\ Dense Shrubbery \\ Scrub \\ Sparse Vegetation Dominated By Trees \\ Sparse Vegetation \\ Carvia callosa patches \\ Open Grassland \\ Rocky Outcrop \\ Free Face \\ Agriculture \\ Settlement, including nearby Bamboo Plantation \\ Non-native Plantations \\ Horticulture \\ Road \\ Area Affected By Road \\ Bamboo \\ Non-native Plantations with regenerating Natives \\ Modern Development \\ Quarry \\ Current Shifting Cultivation \\ Potential Stream habitat \\ Reservoir \\ Total
}

$\begin{array}{ll}\text { Area (Acre) } & \text { Percent } \\ 1542.16 & 5.26 \\ 1319.95 & 4.50 \\ 1026.05 & 3.50 \\ 7034.84 & 23.98 \\ 2052.47 & 7.00 \\ 1502.26 & 5.12 \\ 821.31 & 2.80 \\ 1545.06 & 5.27 \\ 2558.51 & 8.72 \\ 2616.16 & 8.92 \\ 651.97 & 2.22 \\ 25.38 & 0.09 \\ 1571.16 & 5.36 \\ 441.76 & 1.51 \\ 289.7 & 0.99 \\ 44.94 & 0.15 \\ 209.73 & 0.71 \\ 27.98 & 0.10 \\ 1.25 & 0.00 \\ 83.28 & 0.28 \\ 195.6 & 0.67 \\ 3.56 & 0.01 \\ 158.21 & 0.54 \\ 34.61 & 0.12 \\ 3581.83 & 12.21 \\ 29339.73 & \mathbf{1 0 0} \%\end{array}$

Table 5 : Area Statement of Vegetation Classes, 2014
5.26

3.50

23.98

7.00

5.12

5.27

8.72

8.92

0.09

5.36

1.51

0.15

0.71

0.10

0.00

0.67

0.01

0.54

0.12

$100 \%$

\section{Consolidated classes}

Since the above classification had a large number of classes, the 24 land classes in the above table, except reservoir, were clubbed into 5 major land classes. This was based on the observations made during surveys and similarities in characteristics across land classes. Across these consolidated land classes, the status of biodiversity in the catchment was well-represented.
Consolidated Classes
Classes merged
Mature forest
Mature Forest, Tall Canopy, Potential Stream habitat
Dwarf canopy
Dwarf Canopy, Carvia callosa and Dwarf Canopy, Dense Shrubbery
Scrub
Scrub, Sparse Vegetation Dominated By Trees, Sparse Vegetation,
Carvia callosa patches
Open grasslands
Open Grassland, Rocky Outcrop, Free Face
Human use
Agriculture, Settlement with Bamboo Plantation, Non-native Plantation, Horticulture, Road, Area Affected By Road, Bamboo, Non native Plantations with regenerating Natives, Modern Development, Quarry, Current Shifting Cultivation

Table 6: Table depicting the consolidated land-use land-cover classes, 2014 study 
A qualitative description of these consolidated land classes is provided below.

Mature forest: The areas that have near original semi-evergreen vegetation, continuous canopy cover and represent the climax stage of forest.

Dwarf canopy: This class consists of dense shrubs and medium height trees in combination with Carvia callosa.

Scrub: This class contains areas with sparse, scattered vegetation, without much of canopy cover. This area is marked by some tress growing sparsely.

Open grasslands: This land class covers areas which are dominated by seasonal grass. It appears extremely dry and barren during the summer season. Grasses grow here only during the rainy season. It also contains exposed boulders of basalt- the significant rocks of Deccan plateau.

Human use : This class contains land use directly related to human interaction.

The table below provides an area statement for the 1985 study under the set of 5 consolidated land classes.

\section{Land use}

Merged classes

Areas under merged classes (acres)

$\begin{array}{lll}\text { Mature forest } & \text { Mature forests }+ & 1853.70 \\ & \begin{array}{l}\text { Tall canopy } \\ \text { Dwarf canopy }\end{array} & \begin{array}{l}\text { Dense shrubbery } \\ \text { Dwarf canopy }+\end{array} \\ & \text { 10076.76 } \\ & \text { Carvia callosa } \\ \text { Scrub } & \text { Scrub } & 1908.67 \\ \text { Open grasslands } & \text { Open grasslands } & 10507.10\end{array}$

Total

24346.23

Table 7: Area Statement for consolidated land use classes, 1985 study

The table below provides an area statement for the 2014 study under the set of 5 consolidated land classes.

\section{2
3
4
5}

No. Land class

Mature forest
Dwarf canopy
Scrub
Open grasslands
Human use

Total
Area (acres) Percent (\%)

$\begin{array}{ll}2896.72 & 11 \\ 10113.36 & 39 \\ \mathbf{6 4 2 7 . 1 4} & 25 \\ 3293.51 & 13 \\ \mathbf{3 0 2 7 . 1 7} & 12 \\ & \\ \mathbf{2 5 7 5 7 . 8 9} & \mathbf{1 0 0}\end{array}$

Table 7A: Area Statement of the consolidated land use classes, 2014 study

It is evident from present study that area under mature forests i.e. the near original semi-evergreen forest cover in Sahyadri is not sufficient $(11 \%)$ and it is largely present in the high rainfall zone within catchment. The reason for the latter could be this zone is little away from city center and the fact that a direct road up to this zone was made recently (2010). Presence of Sacred Groves, the largest one at Mangao ( 40 acres) has contributed majorly to this land class. So it is observed that preservation of mature forest is directly and inversely impacted by nearness and access from the city.

\section{Analysis of changes in land-use land-cover classes from 1985 to 2014}

As per Tables 7 and 7A, the total areas under the consolidated five land classes from the 1985 and 2014 are different. This is because the map of the 1985 study was originally prepared manually and then digitized in the 2014 study. However, the difference between the total areas of 1411.66 acres is only $5.5 \%$ of the total area from the 2014 study (refer to tables 7 and 7A). Since this is a relatively small percentage difference, we believe it is fair to compare the changes in land-use land-cover over the period 1985-2014. Here we have the following key observations :

- Area in acres under Mature Forest has increased significantly (1043 acres) from 1985 to 2014. This could be due to better protection of reserve forests. However as a \% of total area, it is still low at $11 \%$ in 2014, as discussed above.

- Area under Dwarf Canopy has increased by an insignificant amount (36.6 acres) from 1985 to 2014

- Area under Open Grasslands has decreased significantly (7213 acres) from 1985 to 2014. In the 
1985 study, a relatively larger portion of the catchment was under shifting cultivation and this area was likely counted under Open Grasslands. Our 2014 socioeconomic study for the Panshet catchment (published simultaneously) points to three trends over the last 30 years : 1 . Farmers have left more part of their land permanently fallow. 2 . Where cultivation continues, the land under shifting cultivation has declined, and 3. Overall land under active agriculture has declined by around $33 \%$. As a result of these trends, a large part of land which was potentially under shifting cultivation and classified as Open Grasslands in 1985 has returned to it's natural stage and is now in the stage of scrub land. This is also a possible reason for Scrub land increasing by 4518.46 acres from 1985 to 2014. Additional study is needed to confirm these trends. These changes are summarized in the table below. mentioning that such intensification often results in exhaustion of resources and has undesirable effects on quality of human life in immediate surroundings. This adversely affects the local communities that are directly dependent on the quality of natural resources.

(Gole P., 1985) proposed a way out that will ensure a long life for reservoir, ensure ecological integrity and also protect local livelihoods, giving planned occupations for the local communities. However the current situation in the catchment has changed in the direction of further erosion of natural resources.

It is evident from our observations that man-made activities such as road constructions, modern development and construction have considerably increased, with irreversible impacts on natural ecosystems. The current and future threats to natural resources in this catchment come from uncontrolled, unplanned private developments.
Land use

Mature forest
Dwarf canopy
Scrub
Open grasslands

\begin{tabular}{ll}
\multicolumn{2}{c}{ Area (acres) } \\
$\mathbf{1 9 8 5}$ & $\mathbf{2 0 1 4}$ \\
& \\
1853.70 & 2896.72 \\
10076.76 & 10113.36 \\
1908.67 & 6427.13 \\
10507.10 & 3293.51
\end{tabular}

\section{Difference}

Increased by 1043 acres Increased by 36.6 acres Increased by 4518 acres Decreased by 7213 acres

Table 8: Changes in land use from 1985 to 2014

Additional results of the study are as follows :

- While the area under human use was not mapped separately in 1985, anecdotal evidence and the present study reveals a significant increase in modern developmental activities like farm houses, roads, etc. Modern Development, Roads, and Area affected by Road together constitute 433 acres and $1.5 \%$ of the catchment as per the 2014 study and trends indicate this is likely to grow over the next 12 decades.

- Change in land ownership from locals to developers has shown a positive impact on few areas where the shifting cultivation has stopped due to change in ownership. This was noted during the socioeconomic surveys and is observed by local people over 2 decades.

\section{Conclusion}

(Gadgil M., 1979) has discussed the intensification of resource use with respect to dams and its consequences on forests in Sahyadri. It is worth
From the study it can also be said that given a chance, natural succession happens and takes nature to the next seral stage in the ecosystem development (e.g. Open Grasslands transforming into Scrub). However this is a relatively slow process compared to the present rate of degradation.

Due to importance of natural resources in Sahyadri, the future lies in sustainable landscape level management of the region that will safeguard the ecology and provide long-term benefits from well managed landscapes.

Such an integrated effort will need strong political will, ecologically-sensitive landscape-oriented planning and concerted effort for sustainable development from all sections of society.

\section{References}

1 An Enquiry into the status of animal and plant life in critical areas of Western Ghats in order to evolve a plan to conserve their biological diversity. Ecological Society. - By Gole P., 1985, 
2 Applications of Geographic Information Systems, remote sensing and a landscape ecology approach to biodiversity conservation in the Western Ghats, Current Science, VOL. 73, NO.2, 25 JULY 1997 By Shaily Menon, Kamaljit S. Bawa, 1997

3 Biodiversity Significance, Landuse Pattern And Conservation Of Malayattur Forests In The Western Ghats Of Kerala, India, Indian Journal of Fundamental and Applied Life Sciences ISSN : 2231-6345 (Online) An Online International Journal Available at http://www.cibtech.org/ jls.htm 2011 Vol. 1 (4) October-December, pp.247254/Sakthivel and Sreekumar

4 Changes in land use/cover using geospatial techniques: A case study of Ramnagar town area, district Nainital, Uttarakhand, India- By J.S. Rawat, Vivekanand Biswas, Manish Kumar

5 Dams and Tribal People in India, Contributed to World Commission on Dams - Amrita Patwardhan

6 Deforestation and land use changes in Western Ghats, India - by Jha, Dutt, Bawa, July 2000, Current Science, VOL. 79, NO. 2, 25

7 Eco-restoration potential in the degraded watershed areas of the western ghats Proceeding of International Conference SWRDM-2012, - by Amruta Kurane and Jay Samant Dept. of Environmental Science, Shivaji University, Kolhapur, DEVRAAI (Development Research Awareness and Action Institute)

8 Forest degradation in Western Ghats biodiversity hotspot: Resource collection, Livelihood concern and sustainability - by Priya Davidra, Pratheesh C. Mammen, J.P. Garrigues and Krista Roessingh, Department of Ecology and Environment Sceince, Pudducherry

9 Forest cover change detection of Western Ghats of Maharashtra using satellite remote sensing based visual interpretation technique - By Rabindra K. Panigrahy, ${ }^{*}$, Manish P. Kale1, Upasana Dutta, Asima Mishra, Bishwarup Banerjee and Sarnam Singh. Geomatics Solutions Development Group, Centre for Development of Advanced Computing, Pune 411 007, India, Forestry and Ecology Division, Indian Institute of Remote Sensing, Dehradun 248 001, India

10 Geospatial Mapping Of Potential Recharge Zones In Parts Of Pune City, Geological Society of India, Vol. 73, May 2009, pp.621-638- Duraiswami. R. A., Dumale. V., Shetty U.

11 Hills, dams and forests - by Gadgil M, 1979,
Indian Institute of Science, Vol C2, Part 3, September 1979

12 Land use and land cover change detection through remote sensing approach : A case study of Kodaikanal taluk, Tamil nadu - by Prakasam.C, Department of Geography, The University of Burdwan

13 Land Use And Land Cover Dynamics of Nilgiris District, India, Inferred from Satellite Imageries by American Journal of Applied Sciences 11 (3) : 455-461， 2014 ISSN : 1546-9239@2014 Science Publication doi:10.3844/ajassp.2014.455.461 Published Online 11 (3) 2014 (http:// www.thescipub.com/ajas.toc) Corrosponding Author Nalina, P., 2T. Meenambal and 3R. Sathyanarayan Sridhar, Department of Civil Engineering, Avinashilingam University for Women, Coimbatore-641 10, India

14 Land Use Land Cover in the Western Ghats, India, Effects of Human Modification and Use on Protected Areas - By Malissa Hubbard, Elizabeth Norment, Paul Gerlach, May 2013

15 Land Use Pattern in India and Karnataka: A comprehensive Analysis - By Dr. Premkumara

16 Land Use Changes in India and its Impacts on Environment - By Shashi Chawla Department of Applied Chemistry and Environmental Sciences, Amity School of Engineering and Technology

17 Onchan, Tongroj. 1991. "Asian Agriculture : Perfomance and Issues with Special Emphasis on Thailand", paper presented at the APO Advisory Group Meeting, Tokyo.

18 Population Growth, Changes in Land Use and Environmental Degradation in India - By Ms. Soumya Mohanty, Research Scholar, IIPS.

19 Western Ghats Protection And Sustainable Development- Challenges Ahead - by Aditya Raju and ${ }^{*}$ Dr. K. V. Raju, M G University Research Centre in Economics, S. H College, Thevara, Kochi, Kerala, India

20 WGEEP Report Executive Summary August 9, 2011

21 Ghate, K., Management of Forests in the Northern Western Ghats, Journal of Ecological Society, v. 26 and 27, 2014, pp. 29-42

22 UNESCO 2012 - India - UNESCO World Heritage Centre, http://whc.unesco.org/en/statesparties/ in

23 Gadgil, M. and Vartak, V.D. (1976), Sacred groves of Western Ghats of India, Economic Botany, 30 : 152-160. 